\title{
ENTREVISTA COM JOE HORSE CAPTURE ${ }^{1}$
}

\author{
MARIANA FRANÇOZO' \\ UNIVERSIDADE DE LEIDEN, HOLANDA
}

MARTIN BERGER ${ }^{3}$

NATIONAL MUSEUM OF WORLD CULTURES, HOLANDA

\begin{abstract}
INTRODUÇÃO: Joe Horse Capture é membro da nação A'aniiih (Montana). É especialista nas culturas dos povos indígenas da região dos Great Plains na América do Norte e tem mais de vinte anos de experiência como curador em museus norteamericanos. Atualmente é Vice-Presidente das Coleções Indígenas e Curador de História e Cultura Nativas Americanas no Museu Autry, em Los Angeles, California. Durante os meses de dezembro de 2019 e janeiro de 2020, Joe foi pesquisador convidado do Centro de Pesquisa em Cultura Material, em Leiden, Holanda. Ali, além de trabalhar na preparação de uma exposição sobre arte e cultura dos povos nativos da América do Norte, Joe também deu palestras e concedeu a presente entrevista. Nela, ele fala sobre a questão da representação e autorrepresentação indígena nos museus norte-americanos numa perspectiva histórica. Trata do movimento Red Power nos Estados Unidos na década de 1970; do impacto da legislação NAGPRA na década de 1990; e dos novos modelos de curadoria indigena e curadoria compartilhada que atualmente estão sendo desenvolvidos em museus por todo o mundo.
\end{abstract}

\footnotetext{
1 Agradecemos a Joe Horse Capture pela concessão desta entrevista, bem como por ter revisado a transcrição original de nossa conversa (em inglês). A tradução do texto é de autoria de Mariana Françozo. Este trabalho é parte do projeto de pesquisa BRASILIAE. Indigenous Knowledge in the Making of Science, dirigido pela Dra. M. Françozo na Universidade de Leiden e financiado pelo European Research Council Horizon 2020 Research and Innovation Programme (Agreement No. 715423).

${ }^{2}$ Professora de museologia da Faculdade de Arqueologia da Universidade de Leiden, Holanda. E-mail: m.francozo@arch.leidenuniv.nl.

${ }^{3}$ Curador das coleções Meso- e Sul-Americanas do National Museum of World Cultures, Holanda. E-mail: martin.berger@,wereldculturen.nl.
} 
Mariana Françozo (MF): Pensei que poderíamos começar falando um pouco sobre sua trajetória. Como você decidiu se tornar curador?

Joe Horse Capture (JHC): Sou a segunda geração de curadores na minha família. Meu pai, George Horse Capture, Sr., foi um dos primeiros curadores nativos dos Estados Unidos. Muito disso começou para o meu pai quando moramos na Califórnia anos atrás. O pai dele - de quem eu herdei o nome - foi para a Califórnia como parte do programa de realocação nos anos $50 .{ }^{4}$ Então meu pai seguiu meu avô e conseguiu ali um bom trabalho. Meu pai era como um soldador ou um inspetor de soldagem, e era ao mesmo tempo um indígena. Ele costumava se descrever da seguinte maneira: era um indígena que estava realmente tentando levar a vida do homem branco. Lembro que ele vestia seu terno, gravata e seu chapeuzinho, e carregava uma maleta para cima e para baixo. E esse foi o mundo em que vivi por vários anos. Então Alcatraz aconteceu. ${ }^{5}$ Meu pai descreveu isso como se algo dentro dele tivesse acordado. Então ele foi para a ilha e levou meu irmão mais velho e eu. Eu tinha talvez 10 anos, algo assim. Fomos até lá e, é claro, eu não conseguia entender porque tinha menos de 10 anos de idade. E acho que para o meu pai foi um grande momento. Era o final dos anos 60 na Califórnia, na Bay Area, e o que ele fez foi deixar o emprego e matricular-se em uma universidade local, que na época era Berkeley, no final dos anos 60.

Ele acabou se formando em antropologia. Então nos mudamos para Montana e [ele] terminou seus estudos e começou a lecionar, e acabamos em Cody, Wyoming, onde ele trabalhou como o primeiro e único curador nativo do Plains Indian Museum. É uma coleção grande. E foi aí que eu fui para a escola. Eu me formei no ensino médio lá. Então, eu fui criado essencialmente dentro desse mundo. E quando eu era mais jovem, nos meus 20 anos - [nessa época da vida] um de seus pais geralmente fica Ihe dizendo: "Bem, você deve fazer isso. Você deve fazer aquilo. Você deve fazer isso". Claro, você nunca ouve seus pais porque essa é a regra. Eventualmente, consegui um estágio no Minneapolis Institute of Art [MIA] para trabalhar em exposições antes de ir para a faculdade. Eu ficava pensando comigo mesmo: "Eu realmente não sei muito sobre objetos, então isso vai ser interessante". No fim das contas descobrimos que eu sabia sim, pois havia aprendido não apenas quando criança através daquilo que estava ao meu redor, mas também aquilo que aprendi com meu pai. E então me lembro que houve um momento específico em que eu disse: "Caramba, meu pai estava certo. Maldito seja." Que este é um campo [de trabalho] para mim. Por fim, voltei para Montana, fui para a

\footnotetext{
${ }^{4}$ O Termination Act de 1953, um programa do governo federal dos EUA com objetivo de abolir as comunidades indígenas, deu origem ao programa de realocação urbana voluntária dos indígenas americanos, depois formalizado como Indian Relocation Act em 1956. Organizado pelo Bureau of Indian Affairs, o programa promovia a realocação dos indígenas de suas terras tradicionais para regiões metropolitanas previamente definidas, onde o governo ajudaria na obtenção de moradia e emprego, com objetivo de assimilação dos indígenas à população urbana.

5 Referência à ocupação da ilha de Alcatraz, protesto político organizado por dezenas de indígenas e apoiadores que durou um ano e meio entre 1969 e 1971. O evento teve papel fundamental na consolidação da luta pelos direitos indígenas e do ativismo indígena nos Estados Unidos.
} 
Espaço Ameríndio

universidade, consegui apenas um diploma de bacharel e depois já fui chamado de volta ao Instituto de Arte de Minneapolis como curador assistente. Então você sobe na cadeia alimentar curatorial, certo? De curador assistente para curador associado, e eu fiquei lá por 15 anos. Fui recrutado para ir ao National Museum of the American Indian [NMAI], onde fui curador associado. Trabalhei em coleções e fiz pesquisas lá. Depois fui para a Sociedade Histórica de Minnesota, em Saint Paul, Minnesota, e fiquei lá por alguns anos. Lá, fui o primeiro diretor do Departamento de Iniciativas dos Nativos Americanos. Muito do nosso trabalho foi recrutar comunidades nativas. Eu saí de lá em agosto passado [2019] e agora em março [2020] estarei no Autry Museum of the American West, em Los Angeles. Serei o Vice-Presidente de Coleções Nativas e o curador de História e Cultura dos Povos Nativos Americanos. Vou ter que ter um cartão de visita de tamanho extragrande, meio que dobrado e que tem quer ser desenrolado.

\section{Martin Berger (MB): Como uma carta!}

JHC: Exatamente! [risos] Mas acho que durante todo esse tempo, principalmente quando eu estava no Instituto de Arte de Minneapolis, muito disso foi direcionado [para a área de] arte porque aquele é um museu de arte. Temos certamente uma prioridade diferente, esse [Autry Museum] é um museu de história ou museu etnográfico. Além disso, o que era importante para mim através do meu pai e também do homem que me contratou, o Dr. Evan Maurer - que agora se aposentou e é meu mentor - é descobrir como uma pessoa deve servir à sua comunidade. $E$ para mim, é minha comunidade imediata, minha tribo em North Central Montana, mas também a comunidade nativa como um todo. Então, ao longo desta "carreira" - eu sempre coloco isso entre aspas, porque "carreira" é algo que você frequenta e depois sai, mas, tendo esse tipo de trabalho, você nunca sai de verdade. E uma certa parte de você nunca vai sair, porque está sempre lá. Torna-se parte de você simplesmente porque você tenta descobrir como a coisa funciona. Venho fazendo isso há mais de 20 anos, e isso sempre corta o coração das pessoas, mas não sei como explicar como funciona, porque esta é uma nova era no sentido de como usar museus, coleções e informações. Existem alguns exemplos que já foram feitos e que podemos seguir, mas não sabemos se eles vão funcionar. Este modelo pode funcionar para algumas comunidades, ou não. Aquele pode funcionar para outras comunidades, pode não. Eu sei que no mundo dos museus e no mundo acadêmico, tudo precisa ser organizado.

\section{MB: Compartimentado.}

JHC: Exatamente, compartimentado. Tudo precisa estar em uma caixinha perfeita e é preciso colocar um pequeno laço nela, colocá-la de lado e chamar de bom. Não é desse jeito. Simplesmente não é assim. Quando obras / objetos são retirados de uma comunidade de maneira honrosa ou, na maioria das vezes, de maneira desonrosa, eles são removidos. E 
então a comunidade tem vários desafios pela frente, seja no tocante à cultura, religião, arte, filhos, mulheres, modo de vida, quem são. Tudo isso fica comprometido. Parte do nosso trabalho é apoiar os esforços que eles fazem não apenas para tentar se reconstruir e se sustentar, mas também para se revigorar. É uma mudança tão extensa tentar trazer as coisas de volta. É claro que nunca pode voltar a ser igual, mas tentar trazer as coisas de volta e entender como elas podem ser usadas - porque realmente isso não foi feito. Acho que parte desse processo, pelo menos parte do processo que venho tentando descobrir há 20 anos, é saber como funciona isso. Eu não sei. Eu realmente não sei.

Eu moro nas cidades gêmeas ${ }^{6}$ e jogo lacrosse tradicional. Tenho 56 anos e é um esporte para jovens.

\section{MB: É um esporte difícil também.}

JHC: Sim. Bem, eu jogo lacrosse misto, então é um jogo leve, mas é um esporte para jovens. Portanto, os grupos com os quais eu jogo costumam ter metade da minha idade e eu tento acompanhar. Normalmente, uma vez por ano, acabo me machucando, distendendo um músculo, minha perna ou meu tornozelo ou algo assim, de modo que fico mancando por algumas semanas e depois vou jogar de novo. Mas é divertido. Eu gosto. Você senta e começa a conversar com as pessoas. E eles entendem que eu sou mais velho e tenho cabelos grisalhos, então eles naturalmente pensam - e eu realmente odeio dizer isso - eles podem me ver como um ancião - eu entendo isso. Não me vejo assim nem nunca vou me ver assim. Então conversamos e tudo mais. Tem um casal ótimo. Eles têm um bebezinho. Estávamos falando de criar filhos. Eu tenho uma filha que tem 26 anos. E aí, você pode dizer que eles estavam meio que tentando buscar algum conselho ...

MB: conselhos para os pais.

JHC: Então, estávamos apenas conversando. Eu disse: "Bem, é assim que eu penso e blá, blá, blá, blá, blá, blá". E eu disse: "Joseph, tenho que ser honesto com você". Existe essa percepção de que os idosos sabem tudo, que já descobriram tudo. Isso não é verdade. Os idosos são como jovens, mas com muito mais experiência para entender quando ficar quieto e quando não fazer algo e tentar mudar seus hábitos, tentar ter paciência para descobrir as coisas. Muitas vezes, os jovens não têm paciência. E, é claro, eles ficaram pasmos [quando eu disse isso]. Essa é apenas a minha opinião. Talvez alguns idosos saibam disso, mas os idosos são usados como referências. Mas muito disso é apenas tentar descobrir. E eu trago isso à tona porque acho que é semelhante à situação em questão, isto é, como usamos os recursos que temos, em um museu ou em um centro de pesquisa ou em uma biblioteca ou arquivo ou onde quer que seja, para

\footnotetext{
${ }^{6}$ A região das cidades de Minneapolis e Saint Paul, em Minnesota, é comumente conhecida como "twin cities", cidades gêmeas.
} 
ajudar os povos indígenas. Estou usando isso em um contexto mais amplo. Nós realmente não sabemos. Podemos apenas tentar, e não haverá uma receita única.

MF: Então, sob essa perspectiva, o que você diria sobre suas experiências no MIA e no Museu Nacional do Índio Americano em Washington - como elas diferiram? Afinal, o Museu Nacional é simplesmente enorme. É um museu de e para e por e com povos indígenas.

\section{MB: $E$ bem no centro do poder!}

JHC: Bem, o MIA também é uma coleção muito pequena, e muito do trabalho que fizemos lá foi focado em projetos, em oposição ao NMAI. No entanto, o problema de uma instituição tão grande é que existem muitos desafios e, em uma instituição grande, os recursos podem ser escassos às vezes. Quando você tem uma grande instituição, as prioridades às vezes mudam. Mas a parte boa disso [NMAl] é que há a coleção, que é cerca de 800.000 obras. Gostei do meu tempo no NMAI. Um dos projetos que fiz lá foi trabalhar com os Crow. Eles são das planícies, do sul de Montana Central. O NMAI tem cerca de 600 obras deles, e eu tinha que ir conhecer as pessoas, viajar, fazer uma visita a elas e participar de algumas de suas celebrações. Eventualmente, o que fiz foi tentar descobrir uma maneira de trocar informações com eles. Então eu ia para lá, passava alguns dias e levava um PowerPoint com imagens de objetos Crow e fotografias da coleção [do museu]. Eu os mostrava para vários públicos diferentes, às vezes o grande público geral ou então... - os Crow têm uma comunidade muito ativa que trabalha com contas. Estávamos em uma sala inteira cheia de mulheres e dois homens que são todos artesãos que trabalham com contas e que não necessariamente têm a chance de ver obras históricas. Passamos por cada uma delas e falamos sobre elas. E quando as veem, eles dizem: "Sim. Minha avó fazia esse tipo de design, mas ela geralmente usava essa cor e aquela cor". Portanto, foi uma grande troca, o mesmo com algumas pessoas mais velhas, idosos e jovens. Foi muito divertido. Então, quando esse projeto começou lentamente a ser concluído, fiz questão de que todas as informações que tínhamos no livro de registros do museu estivessem em formato digital, assim como todos os objetos em formato digital, e os coloquei em CDs ou em pen drives. Enviei-os para os artesãos, enviei-os para o tribal college. ${ }^{7}$ Foi ótimo.

\section{MF: Você está trabalhando em outros projetos deste tipo atualmente?}

JHC: Provavelmente de todos os projetos que já fiz, o que mais me orgulha é o da minha comunidade. Somos um grupo pequeno, existem cerca de 4.000 de nós. Atualmente, somos conhecidos como Gros Ventre.

\footnotetext{
7 "Tribal colleges and universities" são instituições de ensino superior nos EUA que servem às comunidades indígenas. Estão normalmente localizadas dentro ou perto de reservas indígenas e são controladas e organizadas por indígenas. Surgiram como resultado do movimento em prol da autodeterminação indígena nos anos 1960.
} 
Espaço Ameríndio

O nome que chamamos a nós mesmos é A'aniiih, que significa povo do barro branco. Somos de uma pequena reserva em North Central Montana chamada Fort Belknap. As obras que criamos muitas vezes são difíceis de encontrar porque somos difíceis de identificar devido a vários fatores diferentes. Um dos projetos em que meu pai passou a vida trabalhando foi tentar colocar tudo o que podia - como material escrito, fotografias, arquivos e objetos - em um grande banco de dados, e eu o ajudei em parte disso, ajudei a trabalhar na parte dos objetos. Além disso, fiz uma pequena exposição no Instituto de Arte de Minneapolis com apenas 40 objetos. ${ }^{8}$ Meu pai escreveu um catálogo bem pequeno. Foi financiado pela Fundação Ford. E há algumas coisas pelas quais fiquei particularmente feliz. O número um é o catálogo - eu escrevi uma parte dele. Um professor de nossa faculdade em nossa reserva, Sean Chandler, também escreveu. Meu pai escreveu. Foi uma exposição com curadoria de membros do grupo indígena, e o catálogo foi escrito apenas por membros do grupo. O catálogo nunca esteva à venda, mas foi doado aos membros do grupo. Eu tenho alguns catálogos restantes. Mas a maneira como funcionou é que eu meio que divulguei, e se um membro da comunidade indígena quisesse um catálogo, eles me enviavam um e-mail, e eu lhes mandaria de graça. Esse foi um exemplo do uso de coleções e informações para que o grupo tenha acesso a eles.

O banco de dados de meu pai, ele terminou, apresentou-o ao [nosso] povo indígena de várias maneiras e depois faleceu. Uma das coisas em que estou fazendo para levar o trabalho adiante é tentar colocá-lo on-line. No entanto, para acessá-lo on-line, você precisa receber permissão. Para ter permissão, existe um portão, e esse portão sou eu [risos]. Portanto, para ter acesso, você precisa me enviar um e-mail, e eu preciso saber que você é um membro do grupo, quem é sua família e quem você é. E assim, no meu tempo livre, estou trabalhando com o banco de dados do meu pai e fazendo tudo isso loucamente - porque eu não sou uma pessoa versada em tecnologia de maneira nenhuma!, e fazendo toda essa conversão louca e tentando carregar o banco de dados com as imagens apropriadas. "Ei, bem, eu tenho imagens melhores do que as que estão aqui agora?" Você sabe o que eu quero dizer? Então, sim, é épico. É enorme. Ele tem músicas, tem gravações de voz, esse tipo de coisa.

MB: Nesses dois projetos que você mencionou com seu próprio grupo e com os Crow, o que você percebe que esses objetos de museu significam para diferentes grupos de pessoas? Existe uma diferença entre, digamos, idosos e pessoas mais jovens, ou as pessoas reagem da mesma forma? $E$ o que esses objetos significam para eles num sentido espiritual, emocional ou intelectual?

JHC: Não sei se há necessariamente uma resposta padrão para isso. Eu acho que, com alguns membros do grupo, há muito ressentimento pelo

\footnotetext{
${ }^{8}$ Trata-se da exposição From Our Ancestors: Art of the White Clay People, com catálogo de mesmo nome, que ocorreu no MIA entre 2009-2010.
} 
Espaço Ameríndio

quê os museus têm. E o lema deles é: devolva. Ao mesmo tempo, alguns membros do grupo estão interessados em trabalhar com o museu e descobrir como podemos chegar a um terreno comum, museus e povos indígenas. Pessoalmente, sou um defensor de que os museus precisam ajudar os indígenas a criar museus em suas próprias comunidades, porque através do NAGPRA ${ }^{9}$ muitas obras precisam retornar, o que é ótimo. Algumas comunidades têm um desafio de quando as obtêm [de volta], onde as colocar.

\section{MF: O que eles fazem com elas?}

JHC: Algumas comunidades retornam [a obra] à vida cerimonial. Outras cumpriram seu papel, então eles as guardam em algum lugar. E outras vezes eles querem preservá-las. Algumas comunidades têm os meios para fazer isso através de centros comunitários. Outras comunidades não. E acredito que é responsabilidade do museu não apenas facilitar o retorno dos objetos. Por exemplo, algumas coleções podem ter, digamos - estou apenas inventando esse número - 200.000 objetos nativos americanos, e eles têm uma galeria, digamos 2.000. Eles têm uma galeria que só pode acomodar 100. Bem, o que vai acontecer com outros 1.900 ? Eles ficam em alguma reserva técnica com temperatura e umidade perfeitamente controladas [sussurrando]. Está escuro, em uma gaveta sem ácido, e eles nunca são tocados. A única vez que eles são tocados é por uma mão enluvada. E essas obras estão acostumadas a se sentirem vivas. Elas estão acostumadas a serem manipuladas. Elas estão acostumadas a sentir esse amor e o poder de serem usadas. Então, elas estão acostumadas a serem amadas e cuidadas.

\section{MB: Pelas pessoas certas.}

JHC: Pelas pessoas certas, e eu diria que muitas dessas obras podem ficar solitárias. Eu acho que é meio injusto. A comunidade precisa delas, não necessariamente para usá-las, mas para tê-las em sua presença, porque estas são as obras que nossos antepassados, como povos indígenas, deixaram para nós. E precisamos descobrir como fazer isso. Algumas obras certamente precisam voltar às comunidades, e os museus precisam ajudar as comunidades a descobrir isso, se necessário. Algumas obras podem não estar de acordo com os regulamentos estaduais e federais para voltar, mas se você tiver várias centenas de objetos nativos americanos de um grupo indígena específico sentadas em seu porão sem fazer nada, e se a comunidade tiver condições de armazená-las, por que não um empréstimo de longo prazo, um empréstimo de 10 anos? E se os pesquisadores vierem a esse museu para pesquisar objetos, digam: "Bem, você pode vir aqui, mas sabe o quê? Se você quiser ver esses objetos, precisará ir à comunidade porque nós deixamos com eles". Daí os

\footnotetext{
${ }^{9}$ NAGPRA, Native American Graves Protection and Repatriation Act, é uma Lei Federal dos EUA de 1990 que cria parâmetros e diretrizes para a proteção e a devolução de restos humanos, materiais funerários, objetos sagrados e objetos do patrimônio cultural dos povos indígenas norte-americanos para suas comunidades de origem.
} 
pesquisadores se envolvem com a cultura material e precisam se envolver com os povos nativos também.

MB: Eles têm que conversar com as pessoas.

JHC: Falar com pessoas! Baaah! [som assustador] [risos]. Precisamos descobrir uma maneira de fazer isso respeitosamente e trabalhar com essas coisas. Para mim, isso é fundamental. E exposição, como apresentamos essas culturas, ainda que sejam aspectos muito específicos das culturas dentro das exposições? Como fazer isso em vários níveis e de várias maneiras? No início da minha carreira, a voz do curador era soberana. Felizmente, teoricamente, estamos nos afastando disso. Em alguns lugares, o curador pode, muitas vezes, ser tradutor ou moderador. Portanto, com esse modelo, não é necessário ter doutorado. É preciso aprender a trabalhar com as pessoas. É preciso entender o que é sensível, o que não é sensível. É preciso ter a cabeça voltada para a cultura material. Muitas vezes, conheço indígenas que estão muito interessados em trabalhar em museus e são realmente inteligentes e estudiosos, mas não conhecem objetos. E você precisa entender isso e entender as pessoas. Você precisa trabalhar com pessoas. Você precisa se abrir, ser vulnerável. Você tem que ser humano, o que eu sei que é difícil.

MB: Um dos temas sobre o qual eu realmente gostaria de saber sua opinião, e que está muito de acordo com o que você estava dizendo agora, é como você vê essa discussão que está acontecendo no mundo dos museus sobre coleções indígenas sendo curadas apenas por curadores indígenas. Vemos isso na Nova Zelândia, por exemplo, onde há muita discussão. Houve, no Museu do Brooklyn, uma grande discussão sobre uma pessoa que não é negra sendo contratada como curadora das coleções africanas. Como você vê o papel do curador?

JHC: Eu acho que é [um papel] importante. Na minha opinião, existem muitos indígenas que estão se preparando para cumprir esse papel, porque estar nesse papel exige muita responsabilidade e muita experiência. A geração que está passando a ter esse papel agora está começando a ter essa experiência. E acho que a próxima geração de curadores de coleções indígenas quase sempre será indígena. Estamos chegando perto disso agora, mas muitas pessoas ainda estão concluindo seus estudos porque os museus exigem isso. Quero dizer, até o Metropolitan Museum of Art, que recebeu muito feedback - não um feedback positivo, sobre a exposição The Plains Indians: Artists of Earth and Sky. ${ }^{10}$

MF: Foi essa a exposição que eles fizeram junto com o Musée du quai Branly há alguns anos atrás?

\footnotetext{
${ }^{10}$ A exposição ocorreu em 2015. Ver: https://www.metmuseum.org/press/exhibitions/2015/plains-indians
} 
Espaço Ameríndio

JHC: Sim. Eles receberam muito feedback negativo, inclusive da minha parte. Eu escrevi um artigo muito direto. ${ }^{11}$

MB: Desfavorável.

JHC: Eu estava apenas mostrando como torná-la melhor. A exposição que eles têm agora lá da coleção Diker também precisa de melhorias. ${ }^{12} \mathrm{~A}$ boa notícia é que sei que eles estão procurando um curador nessa área. Pelo que entendi, eles preferem contratar um curador indígena. Eles tiveram que procurar por alguns meses. Felizmente, eles vão tomar uma decisão em breve. Mas está indo neste sentido. É difícil ser paciente, porque isso acontece há muito tempo. Mas os museus são como continentes. Movemse muito, muito devagar. Mas, espera-se, quando um continente se move e atinge outro continente, ele cria um conjunto de montanhas que perdura por muito tempo.

MB: Essa é uma boa analogia. O Met, é claro, teve toda aquela história de que a coleção Diker seria doada para eles apenas se fosse aceita como arte americana. Foi isso mesmo?

JHC: Sim. Ainda está emprestada.

MB: Como você vê essa discussão da arte nativa americana sendo incluída nessa ideia de arte americana? Isso é relevante ou importa? E meio que conectado a isso, existe uma diferença entre museus de arte e museus etnográficos vendo esse material como arte?

JHC: Acho que, se voltarmos um pouco aqui na sua discussão, não tenho certeza de que o pedido para colocar obras indígenas na seção de arte americana seja necessariamente o problema. Eu acho que a questão é como os museus estão interpretando o que é arte americana. Muitas vezes, não estamos olhando arte americana e pensando, bem, "arte de pessoas brancas". Mas depois voltamos ao [tema] o que é arte americana? O que é americano? Os assim chamados museus "descolonizados" estão gerações atrasados em sua responsabilidade. E a responsabilidade deles é contar a história completa. Nesse caso específico da arte americana, a responsabilidade deles é contar a história afro-americana, a história nativa americana, a história asiático-americana, a história mexicanoamericana. Tudo isso deve ser incluído no que conhecemos agora como arte americana. Como isso não foi feito, está deixando buracos na história que nós devemos aprender. Dito isto, há várias histórias aqui. Certo? Existe a experiência americana, que é mostrada através da arte

\footnotetext{
${ }^{11}$ A resenha crítica de Joe Horse Capture pode ser lida em: https://indiancountrytoday.com/archive/horsecapture-native-people-have-a-story-to-tell-their-own-cbrUU5jgNU2keWg71W5B g

12 A coleção foi emprestada ao Metropolitan Museum pelo casal de colecionadores Charles e Valerie Diker e está em exposição desde 2018 sob o título de Art of Native America: The Charles and Valerie Diker Collection. Para mais informações, https://www.metmuseum.org/exhibitions/listings/2018/art-of-nativeamerica-diker-collection
} 
Espaço Ameríndio

americana. E dentro disso, cada comunidade tem sua própria experiência. Então, o nativo americano tem sua própria experiência. Afro-americanos tem sua própria experiência. Acredito que cada um deles deve ter sua própria galeria, mas também deve ser colocado dentro da arte americana, porque ainda é uma história cultural, mas também é importante como essa história cultural se encaixa em uma história maior.

Portanto, os museus ainda têm muito a descobrir e cada vez mais, porque estamos avançando muito rapidamente com as demandas do público. Eu tinha um amigo meu que me disse o seguinte. No começo, me pareceu estranho, e então, quando pensei de novo, pensei: "Hmm, acho que ele está certo". Ele disse que os museus precisam se atualizar agora porque estamos em um mundo pós-Pantera Negra. Se pensarmos no filme Pantera Negra, quando ele entra [no museu] e diz: "De onde eles vieram?" E o curador está tomando uma xícara de café - não sei se os curadores ainda tomam xícaras de café dentro do museu. Você se lembra como tudo aconteceu. Eu acho que o que isso fez de maneira brilhante foi atrair pessoas comuns, principalmente pessoas mais jovens ou pessoas comuns, pessoas que não necessariamente se veem ou veem seus antepassados representados no museu. E adivinhe o que as pessoas pensam: "Ei, espere um minuto. Como esses objetos chegaram aqui? Ei, espere um minuto, como é que as pessoas de onde eu venho não estão neste museu?" E com razão, há muita contrariedade nisso. Nos museus, para continuar sendo relevante, você precisa abordar isso. E haverá consequências políticas por causa de pessoas que preferem ver os museus como conservadores. Não vai mais dar certo.

MF: Então, como parte disso - você acabou de mencionar a palavra descolonização, e eu estava pensando em como essas palavras como descolonização ou compartilhamento de poder, compartilhamento de autoridade ou colaboração, elas se tornaram palavras-chave no mundo dos museus e na academia. Você pode dizer algo sobre isso? Você acha que os museus estão descolonizando, o que quer que isso possa significar?

JHC: Bem, alguns museus estão, e outros museus certamente têm mais trabalho a fazer. E alguns museus precisam pegar o bonde andando, ou serão deixados para trás na estação. Agora, a ideia de "descolonização" ou de descolonizar é ótima. Eu apoio 100\%. Se estivermos definindo a descolonização como trazer outras vozes, como repatriação para garantir que as culturas que estão sendo representadas no museu ou dentro da galeria, que as pessoas dessa cultura tenham uma contribuição significativa sobre como estão sendo retratadas. Se estamos definindo a descolonização como abertura a outras narrativas, como contribuição e criação de uma interface para - acho que o termo aqui é comunidade de origem.

Se estiver realmente úmido nesta sala, colocamos um desumidificador porque removemos a umidade. Agora, se os museus são baseados e exclusivamente baseados no processo de colonização, e se colocar o 
"des" na frente da "colonização" significa que você está tirando a colonização... você não pode tirar a colonização de um museu porque os museus são a base do poder colonial. Portanto, "descolonização", o próprio termo é impreciso. Esse é o problema que eu tenho. Ironicamente, precisamos descolonizar o termo descolonização [risos]. Para mim, para meu uso pessoal, prefiro o termo recuperação [reclamation] - e isso pode ser aplicado a todos os outros públicos mencionados anteriormente. Obviamente, meu interesse particular são os povos indígenas. Precisamos recuperar nossas histórias, recuperar como somos retratados, recuperar nossos trabalhos, recuperar o que nossos Antepassados nos deram, recuperar música, recuperar arquivos, recuperar fotografias, recuperar a narrativa, recuperar nosso espaço, recuperar nossa terra, recuperar nossa comida. Todas essas coisas que estamos reivindicando, tudo isso cai sob o guarda-chuva da "descolonização". Mas é realmente recuperação. Estamos reivindicando o que é, em um sentido mais amplo, nosso. Portanto, não tenho nada contra o processo e as ideias da descolonização, mas sei como são os acadêmicos. Eles querem um termo preciso para descrever isso. Na minha opinião, descolonização - não é esse termo exato. É recuperação.

MF: Eu queria mudar um pouco a conversa da América do Norte para a Europa, porque você está aqui há dois meses, me parece, visitando museus, vendo coleções e conversando com pessoas. Como você acha que os museus europeus estão se saindo em termos de apresentar ou tornar acessíveis as coleções dos povos indígenas norte-americanos? Como você avalia os museus europeus dentro desse processo sobre o qual estamos falando?

JHC: Não tenho certeza se posso dar uma avaliação justa, mas o que posso dizer - e visitei tantos museus; estou confundindo todos eles na minha cabeça, para ser honesto. Estou muito impressionado com algumas das exposições que vi em museus europeus, onde eles estão abordando a importância da proveniência. Eles estão abordando a ideia de que esses objetos chegaram aqui de uma maneira desonrosa. E se foi esse o caso, como você vai descobrir isso? Eles estão fazendo isso nas galerias. Eu vi uma exposição. Esqueci onde... não me lembro, era Colônia? Não, eu não lembro. Eles tratavam da prataria judaica que foi confiscada durante a guerra. E eles falavam sobre os bronzes do Benin e outros aspectos. Eles contavam uma história e divulgavam as informações que tinham sobre isso. E, essencialmente, eles estão apresentando ao público [a pergunta]: "Afinal, o que foi que nós fizemos?". Em toda a galeria, todas as legendas desta exposição eram em vermelho. E por toda a galeria, em todo o museu, eles tinham um pequeno triângulo, etiquetas vermelhas, pedaços não identificados de um objeto de origem questionável. E minha cabeça quase que explodiu porque fiquei tão impressionado, afinal o museu é, você sabe, aquela instituição lá no alto da colina. Certo? Então agora alguns museus estão olhando para si e dizendo: "Devemos ter isso?" E, primeiro, quem vai tomar essa decisão? E segundo, quais são os próximos passos a seguir? E pode haver, mas é 
difícil para mim pensar em museus nos EUA que estão adotando essa postura forte em suas galerias públicas. Também havia outro - eu esqueci de onde era - que tinha uma postura semelhante em que eles estavam dizendo: "Bem, de onde isso veio? Deveríamos ter isso? E como isso afeta as pessoas de onde isso veio?" Eu fiquei impressionado.

MF: Acho interessante você dizer que é diferente dos Estados Unidos, porque eu diria que as vozes dos nativos americanos parecem ser muito mais ouvidas nos Estados Unidos do que [as vozes indígenas] aqui.

JHC: Eu acho que sim, mas - e novamente, eu realmente odeio fazer generalizações sobre todos os museus dos EUA - porque alguns estão fazendo um trabalho muito bom. Outros precisam de espaço para se atualizar, mas internamente em museus, certamente existem discussões sobre "Como avançamos?". Nem todos os museus necessariamente querem avançar. Alguns museus dizem, "Bem, como avançamos e vamos além disso?" Então, acho que está acontecendo uma discussão interna. Mas suponho que muito disso [na Europa] tenha a ver com as pesquisas de proveniência, porque as coleções feitas durante a guerra trouxeram à tona todas essas outras questões, o que é ótimo. Eu acho que, a esse respeito, os Estados Unidos têm ainda que melhorar porque esse tipo de discussão, os museus simplesmente não podem ficar sozinhos ao discutilas. Eles precisam atrair o público. Eles precisam trazer as "comunidades de origem" porque é uma discussão mais ampla, e acho que ajuda o público em geral a entender do que se trata o museu. Eles têm coisas bonitas na parede e contam ótimas histórias, mas quem escreveu as histórias? De onde vêm essas coisas? Às vezes é bom, às vezes é ruim, porque se estamos contando histórias, queremos ter certeza de que elas são as histórias certas ou são histórias que vieram das pessoas que são donas delas. Penso que muitas vezes, o público médio dos EUA não pensa necessariamente nisso, mas é um processo. É um processo de educação. E também, é um processo para garantir que os povos indígenas tenham uma significativa participação nas histórias que estão sendo contadas e nas obras, na sua recuperação.

MF: Eu sempre tenho a sensação de que o público em geral não conhece o suficiente sobre essas transformações. Eu vejo isso nos meus alunos. Eles frequentam nossos cursos de museologia e têm uma opinião muito forte sobre os museus, por vezes uma opinião negativa de que os museus não estão fazendo o suficiente, ou "eu vi essa exposição e eles não fizeram isso, eles não fizeram aquilo". Minha impressão é que existe uma enorme lacuna entre o que acontece nos bastidores, o que é exibido e o que as pessoas realmente sabem que está acontecendo nos museus. Como você lida com isso? É possível tornar os processos do museu mais explícitos para o público?

MB: O grupo demográfico de que você está falando, Mariana, é um grupo demográfico muito específico. É geralmente jovem, digamos, estudantes progressistas de esquerda que estão interessados em museus. Se você 
olhar para o contexto político holandês, pelo menos, há uma reação muito grande contra essa ideia de repatriação - no nível político, porque eles dizem [sobre colonialismo e museus]: "Você precisa se orgulhar de quem você é". É um discurso nacionalista muito forte que está lutando contra todas essas mudanças. Penso que, para os museus, também se trata de andar na corda bamba entre fazer o que eles acreditam, que é o que seus alunos querem fazer, e depois falar sobre isso com seus financiadores que, em alguns casos, podem não ser solidários. Eu sinto que nos EUA, uma vez que muitos museus são privados, há uma grande diferença no sentido de que eles não podem fazer declarações políticas, porque as pessoas que os financiam podem não concordar com isso. Não sei se é uma avaliação justa.

JHC: Sim, é o caso. Os museus certamente precisam estabelecer seus valores e cumpri-los, mesmo que isso lhes custe algum financiamento, porque os museus têm uma história importante para contar. Eles têm que ter certeza de estar incluindo várias vozes e garantindo que o futuro de sua coleção seja acessível àqueles que devem ter acesso a ela. No que diz respeito ao processo do museu, estamos trabalhando numa pequena exposição agora. Se você olha para todas as diferentes legendas, os painéis, é preciso que eles tenham um certo número de palavras. E talvez eu esteja errado, mas o texto da legenda é como 60 palavras, e como você explica uma obra em 60 palavras? Para os jovens que dizem: "Os museus fizeram isso errado, fizeram aquilo errado!" Minha resposta é: "Mude isso". Se os museus não estão fazendo o que é certo, transformeos e / ou sente-se com um curador, tome um café e converse com ele. Diga, qual foi o processo? Como você chegou a esse ponto? E o curador que não aceita esse tipo de convite precisa ser questionado. Esse tipo de educação e envolver mais pessoas na paixão por museus e pelo potencial dos museus, isso é bom.

MF: Então, que conselho você daria a esses jovens aspirantes a curadores ou estudantes de museologia?

JHC: O curador é uma das posições mais superestimadas que existe. É porque no passado, curadores meio que tinham isso [aaah]. Certo? Você aparece empunhando uma pequena espada, e a luz está brilhando sobre você. Bem, tudo isso está mudando. Tudo isso vai mudar. Os museus precisam de pessoas realmente boas em arrecadar dinheiro, isso porque o financiamento de que você falou, se você pode ter financiamento do governo, se pode ter financiamento privado - o financiamento privado vem nas mais diferentes formas. Para contar essas histórias, precisamos de financiamento para fazer isso como mencionei antes, mas quem vai educar os jovens que você acabou de mencionar? Precisamos de educadores realmente inteligentes e diversos. Quem vai cuidar fisicamente dos objetos? Precisamos de pessoas inteligentes, sensíveis e diversas para cuidar das coleções. Existem tantas camadas diferentes, tantos aspectos diferentes em um museu que realmente precisam de ajuda. E para ser sincero, quando trabalhei no MIA, havia dois curadores 
nativos no país, eu e Deana Dartt. Ela estava no Museu de Arte de Portland.

Agora há mais, mas os curadores, quando conseguem essa posição, ficam lá até morrerem. Eles ficam lá para sempre. Meu medo é que haja tantas pessoas que querem ser curadoras e que se qualificam como curadoras, mas elas não terão trabalho porque simplesmente não há tantas vagas. Mas existem tantas outras camadas no trabalho do museu em que você pode ter o mesmo tipo de impacto ou até mais. Sobre o futuro do museu, que histórias estão sendo contadas nos museus? Os arquivistas estão trabalhando para tornar o material acessível. Encontre algo que ninguém viu em mais de 100 anos e você desempenhou um papel nisso, trazendo à tona uma história totalmente diferente e uma narrativa totalmente diferente. $\mathrm{O}$ curador tem essa aura de romantismo, mas na realidade não é assim.

MF: Então é realmente um novo momento para os museus, esperamos.

JHC: Deveria ser. Ou será. É uma questão de quem vai estar dentro e quem não vai estar dentro.

MF: E quem não está...

JHC: Eles vão ter dificuldade. Eles serão forçados por pressão política da comunidade ou por pressão política do governo ou pelo financiamento. Você realmente quer garantir que está em sintonia com sua comunidade. E há várias comunidades. Certo? Há comunidades que são representadas pelo público. Existe a sua comunidade local dentro da sua cidade. Há o seu condado, um estado, região, país. Você quer ter certeza de que está em contato com todos eles porque você é um recurso. Você está lá para contar histórias.

MF: Essa transformação, digamos, abertura, democratização ou descolonização dos museus, como podemos fazer isso acontecer quando muitos de nossos países se inclinam para regimes políticos de direita, às vezes quase fascistas?

JHC: Acabei de ler um artigo - foi na BBC? Foi na Alemanha - onde essa diretora - essas comunidades têm muitos fascistas por lá. Eles estavam dando trabalho para ela, mas realmente não era loucura o que o museu [dela] estava fazendo. E o que ela acabou fazendo foi tornar o museu uma plataforma de diálogo. Então, você traz pessoas deste lado e reúne pessoas daquele lado para se encontrarem e ter discussões. Portanto, um museu não é necessariamente apenas uma rua de mão única, onde o museu está contando histórias. Um museu deve ser um local seguro para as pessoas se reunirem para compartilhar histórias e compartilhar experiências. E você pode fazer isso através de seminários, através do diálogo, através de cafés. Você reúne pessoas que não necessariamente se sentam na mesma mesa. Um museu precisa ser, como eu digo - um 
espaço seguro. $E$, por sua vez, o museu através de exposições e programação, através desses diálogos, garante que ele apresenta essas informações. Eu acho que uma das reclamações que este museu [na Alemanha] teve... Ela não estava mostrando o suficiente de obras de arte da Europa Oriental, então [ela] fez isso. E para dar uma guinada, ela mostrou artistas mulheres da Europa Oriental. E acho que o público estava pensando mais em artistas masculinos. Certo? Mas ela disse: "Bem, podemos abrir esse diálogo ainda mais. Vamos mostrar nossas artistas mulheres".

MB: Eu estou aqui há muito tempo como curador. Luto com esta instituição pelo fato de termos uma genealogia tão colonial que não sei se podemos ser redimidos. Você acha que, se você diz que o museu precisa ser um lugar para conversar, acha que podemos fazer isso em museus ou precisamos criar um novo espaço, que se conceba de uma nova maneira e que talvez esse tipo de instituições [museus] morrerão em algum momento e serão substituídas por outra coisa?

JHC: Esses tipos de instituições, suas raízes vão até o núcleo da Terra e surgem do outro lado. Eu acho que elas nunca vão embora. Sua pergunta é: ela pode ser resgatada? Minha pergunta é: qual é a alternativa?

MB: Acho que a alternativa é devolver tudo e começar de novo, mas não sei. Quando você diz que precisamos iniciar conversas, eu concordo totalmente. Eu acho que ter o museu como plataforma é o caminho a percorrer. Mas, ao mesmo tempo, acho que nossa essência é nossa coleção. As coleções, em muitos casos, são problemáticas por várias razões; então, como conciliar isso com a ideia de um museu como espaço de diálogo? E acho que isso pode não ser uma pergunta, mas estou ventilando minhas próprias frustrações [risos]. O que fazemos com todas as coisas que estão aqui, que são valiosas? Podemos usá-las de forma ética? E, se não, como garantir que elas retornem às pessoas que podem fazê-lo, se quiserem? E então, por outro lado, como podemos usá-las para gerar mudanças produtivas não apenas em nossas comunidades, mas nas comunidades em todo o mundo e nos lugares de onde elas vêm? Então, basicamente, a questão é: se você entrar em um museu etnográfico em 100 anos, como você acha que será?

JHC: Uau, eu nunca pensei nisso antes. Eu acho que no "museu" etnográfico, se a direção for para onde está indo agora, parecerá muito diferente no sentido de que as comunidades terão uma quantidade significativa de voz nas histórias que estão sendo contadas e como seus objetos estão sendo usados. Você mencionou anteriormente sobre o que você pode ou não pode usar como objeto. Trabalhe com a comunidade. Faça uma parceria com a comunidade, em vez de [tê-las como] consultoras ou conselheiras. Faça uma parceria com essa comunidade, seja o governo, seja você criar um conselho de pessoas com diferentes especialidades. Assim, ao organizar a exposição, você trabalha em 
conjunto para que eles possam ajudar e ter um papel de $50 \%$ nas histórias contadas e na decisão sobre quando as obras devem ou não ser usadas.

MB: Você acha que deveria ser $50 / 50$ ou $80 / 20$ ou $100 / 0 ?$

JHC: $50 / 50$.

MB: Você acha que metade deve ser determinada pelas pessoas daqui, digamos?

JHC: Por enquanto, 50/50, mas a razão é que pode haver todos os tipos de considerações, seja pela conservação ou seja qual for o caso.

MF: Essa também é uma reflexão interessante para a nossa exposição.

MB: Exatamente. Então, nós estamos trabalhando nos preparativos de uma exposição sobre a Amazônia, ${ }^{13}$ na qual meu objetivo pessoal é não tomar nenhuma decisão em todo o processo da exposição. Eu estou lá como o intermediário que garante que o que as pessoas da Amazônia querem que seja exibido aqui, seja de fato exibido aqui. Pode ser um pouco ambicioso no sentido de que não sei se isso funciona nesta instituição.

JHC: Fiz a mesma coisa também porque venho da velha escola, onde os curadores [aaaah]. E então, nos últimos 20 anos, isso mudou. Pense no seu papel nesta exposição. Seja qual for o seu papel, não como curador, mas como contador de histórias. As obras são as ferramentas que você está usando para contar a história. E a comunidade está determinando quais ferramentas usar, mas ainda assim é sua tarefa contar essa história, porque a comunidade que não vem do mundo do museu não está necessariamente familiarizada com o que será a exposição. Como a história vai fazer sentido? Esse é o seu trabalho.

MB: Esse é um bom ponto, então. Foi o que você mencionou sobre tradução, certo? É tipo curador / tradutor.

JHC: Acho que parte do seu trabalho é garantir que faça sentido do ponto de vista do visitante do museu. E, eventualmente, a próxima geração de curadores ou na geração seguinte, cada comunidade terá seu próprio curador. Então você não vai mais precisar estar por perto. Você não vai precisar tomar nenhuma decisão porque eles já terão isso com eles.

\footnotetext{
${ }^{13}$ Esta exposição sobre a Amazônia, com curadoria principal de Martin Berger, está sendo preparada em tripla parceria pelo National Museum of World Cultures da Holanda, o Santo Domingo Centre of Excellence for Latin American Research do British Museum coordenado por Laura Osorio Sunnucks, e pelo projeto de pesquisa ERC BRASILIAE, coordenado por Mariana Françozo na faculdade de arqueologia de Universidade de Leiden. No momento em que esta entrevista foi feita, anterior ao início da crise Covid-19, planejava-se uma grande exposição, possivelmente itinerante, para 2022. Atualmente estes planos estão sendo revistos em função do impacto da crise para os povos da Amazônia e para as instituições envolvidas.
} 
MB: Este é um bom ponto. Isso se afasta da ideia de que o conceito de museu, que eu acho que está muito enraizado no colonialismo e no pensamento ocidental, é um conceito útil também para as comunidades indígenas. Há também acadêmicos e estudiosos indígenas que pensam que o conceito de museu em si é tão problemático que não pode ser usado porque é visto por pessoas que vêm de fora como uma instituição tão "autorizada" que ela precisa ser uma coisa única, definida. A ideia do próprio museu pode ser problemática.

JHC: É problemático agora, mas não precisa ser problemático daqui a 10 anos. Os museus estão melhores do que eram há 20 anos. E isso é apenas 20 anos atrás. Mas dar esses pequenos passos ajuda.

MF: Só por curiosidade, para o nosso próprio projeto, quando dizemos: "Olha, queremos fazer uma exposição sobre a Amazônia daqui a dois, três anos", o que você imagina ou o que deseja ver?

JHC: Quero ver o que a comunidade quiser [que eu veja]. Quero ver as histórias que a comunidade considera importante para mim, porque, como eu digo, se eu quero ver como elas jogam dardos, essa é a minha própria esquisitice.

\section{MB: Sua associação.}

JHC: Sim. "Como eles fizeram isso? Que tipo de coisa eles colocam na ponta do dardo para abater os animais?" Quero dizer, isso é apenas uma coisa estranha que você coloca na sua cabeça. Não faça uma exposição sobre isso, porque muitas vezes, pelo menos pela minha experiência, quando as pessoas montam uma exposição e trabalham com pessoas de fora da equipe curatorial, elas dizem: "Bem, o público não está interessado nisso." E minha resposta é: "Bom. Vou fazê-los se interessar por isso". Só porque eles estão interessados em certas coisas não significa necessariamente que precisamos preencher todas essas coisas. Tudo bem se as pessoas aprenderem algo novo.

MF: Então, de certa forma, o que você está dizendo é que um museu pode e deve servir à comunidade em que está baseado, o país, o estado, a federação, mas isso não significa um relacionamento direto. Não é um cardápio ou um restaurante sob demanda, certo, onde digo: "Quero ver a plumária", e você me dá plumária.

JHC: Sim. No entanto, se você tem uma grande coleção de penas, pode dizer: "Vamos fazer uma exposição porque temos as melhores plumárias do mundo. Vamos fazer uma exposição sobre penas. Uma quantidade $X$ vem da América do Norte, a quantia $X$ vem da América do Sul, a quantia $X$ vem da África". Então, precisamos descobrir onde esses objetos estão. Como tudo isso vai se unir [na narrativa]? Porque, se você está tratando de uma comunidade, no meu caso, uma exposição específica de um 
grupo indígena, então você traz a comunidade. Se você está fazendo este trabalho sobre plumárias na coleção, não pode realmente fazer isso.

MB: Há uma última coisa que eu estava pensando quando você estava falando no início da nossa conversa, então se eu não o citar corretamente ... [risos]. Foi sobre quem pode falar sobre e pelos objetos. Existe agora toda a tendência nos museus etnográficos de atrair artistas contemporâneos para trabalhar com o material. Eu estava pensando, $o$ que você acha disso? Como você vê a criação cultural contemporânea? Porque agora estamos falando de objetos ancestrais em geral, que estão em museus, mas como você vê artistas indígenas contemporâneos, artistas nativos e outros artistas trabalhando com as coleções - que papel eles podem desempenhar?

JHC: Eu acho que artistas nativos contemporâneos que estão criando obras são muito importantes porque estão apresentando algo de sua própria experiência. Agora, sua própria experiência nem sempre reflete necessariamente que eles têm todo esse conhecimento comunitário sobre objetos históricos. Esse é um recurso diferente. A partir daí, você vai para as comunidades que existem há muito tempo, detentoras de conhecimentos tradicionais. Nos Estados Unidos, nas reservas de comunidades indígenas, existe uma posição geralmente chamada THPO, Oficial de Preservação Histórica Tribal [Tribal Historical Preservation Officer]. Esse papel geralmente é daquele que trabalha com entidades externas sobre coisas culturais que têm a ver com comunidades específicas. Por exemplo, se eles estão colocando uma estrada através de uma área, e essa área pode ter algum tipo de item cultural enterrado - o THPO estará lá para garantir que eles não esbarrem em nada.

Quando um museu quer trabalhar especificamente com uma comunidade por meio de seu governo, geralmente trabalha primeiro com o THPO. Portanto, existem muitas maneiras de obter conhecimento. E também há pessoas que podem não pertencer a esse grupo indígena que são especialistas. Parte da responsabilidade do museu é ajudar as comunidades a reconstruir parte do conhecimento que elas podem ter perdido. Isso não significa necessariamente que as comunidades antigas têm esse conhecimento atualmente, porque ele foi retirado e inserido em museus. E essa geração que estava confinada a reservas foi golpeada com o cristianismo, foi golpeada com o estilo de vida tradicional, golpeada com o modelo europeu de como viver. Portanto, parte desse conhecimento foi extraído da comunidade, principalmente através do cristianismo. Muitas vezes, esse conhecimento vem da antropologia, o que é estranho. Os antropólogos não estavam lá. Mas, ironicamente, os indígenas podem ir ao museu e reaprender seu idioma. É simplesmente uma coisa estranha. Portanto, não há necessariamente uma resposta fácil. Você precisa obter esse conhecimento. Hoje, você precisa trabalhar em vários níveis diferentes. Daqui a duas gerações, você irá à comunidade porque eles mesmos terão esse conhecimento. Mas existem várias maneiras de obtê-lo. 
MF: Talvez você possa falar sobre sua experiência aqui trabalhando na exposição First Americans. ${ }^{14}$

JHC: É tudo de bom. Não houve nenhum tipo de "Ahn, isso é estranho". Meu único problema é a barreira do idioma. Eu não sei holandês, então demorei muito tempo para descobrir como desligar meu computador com Windows. E então, usando o [programa] TMS, ${ }^{15}$ - finalmente descobri como fazê-lo em inglês, mas as informações sobre o objeto estão em holandês. Então, no meu telefone, eu tenho o Google Translate e faço isso o tempo todo. Mas tem sido bom. Eu estou trabalhando com a Henri [Henrietta Lidchi], ${ }^{16}$ e ela está fazendo muitas coisas com suas responsabilidades profissionais aqui. Estou aqui para apoiá-la e tentar levar a exposição adiante o mais que puder. Isso é uma espécie de resposta à P2020, a coisa dos pilgrims. ${ }^{17}$ Essencialmente, [First Americans] é sobre os povos nativos americanos hoje. Lidamos com algum material histórico, primeiro contato, como as comunidades nativas eram vistas pelos novos visitantes. E então mudamos para o futurismo e como alguns artistas nativos estão olhando para o futuro. Nós falamos sobre resiliência. Falamos sobre indígenas urbanos. Falamos sobre soberania alimentar, falamos sobre linguagem. Estamos todos montando isso juntos, mas eu tenho um pouco mais de duas semanas e estou tentando terminar as coisas. Mas tem sido bom. Eu estou gostando. Quer dizer, todo mundo tem sido extremamente legal. As pessoas aqui na Holanda são muito legais, são quietas, muitas bicicletas. Eu cheguei aqui no início de dezembro e partirei no final de janeiro. Nesse meio tempo, eu esqueci como é o sol, só o vi hoje. [risos].

\section{MB: E seu trabalho em Los Angeles, como vai ser?}

JHC: Bom, esta é uma boa pergunta. Acho que será trabalhar com comunidades nativas para garantir que estamos recebendo as histórias adequadas para as coleções. A coleção, muito dela, é da região cultural do sudoeste americano. Assim, parte disso será trabalhar com o pessoal do sudoeste para nos ajudar a entender o que é [que temos] e também criando exposições que contam uma boa história da maneira que eu descrevi cerca de uma hora atrás [risos]. Então será interessante. É um museu de médio porte. Já trabalhei em museus realmente grandes, três deles, então estou ansioso por isso, porque a parte boa de um museu de médio porte é a flexibilidade e a mente aberta para experimentar coisas novas.

\footnotetext{
${ }^{14}$ A exposição temporária First Americans ocorre a partir de julho de 2020 no Museu Nacional de Etnologia em Leiden.

15 TMS, ou "The Museum System", é um software comumente usado para gestão de coleções (de museus, arquivos, etc) em diversas instituições em todo o mundo.

${ }^{16}$ Henrietta Lidchi é antropóloga e curadora-chefe do National Museum of World Cultures, Holanda.

17 No ano de 2020 comemoram-se os 400 anos da chegada dos pilgrims ("peregrinos") ingleses, que partiram da cidade de Leiden no navio Mayflower para fundar uma colônia na América do Norte. Várias instituições comemoraram este marco histórico com exposições, palestras, etc. Tais eventos comemorativos ficaram conhecidos como P2020.
} 
Espaço Ameríndio

MB: Legal, de volta à Califórnia!

JHC: Sim, 30 e poucos anos depois. A parte boa disso é que vou ver o sol!

Recebido em: 11/07/2020 * Aprovado em: 11/09/2020 * Publicado em: 11/09/2020 